\title{
Do Government Policies that Promote Competition Encourage- or Discourage—New Product and Process Development IN LoW ANd Middle-Income Countries?
}

\author{
George R.G. Clarke*
}

\section{World Bank Policy Research Working Paper 3471, January 2005}

The Policy Research Working Paper Series disseminates the findings of work in progress to encourage the exchange of ideas about development issues. An objective of the series is to get the findings out quickly, even if the presentations are less than fully polished. The papers carry the names of the authors and should be cited accordingly. The findings, interpretations, and conclusions expressed in this paper are entirely those of the authors. They do not necessarily represent the view of the World Bank, its Executive Directors, or the countries they represent. Policy Research Working Papers are available online at http:/lecon.worldbank.org.

\footnotetext{
*
}

The data used in this paper are from the Business Environment and Enterprise Performance survey (BEEPS II) C2002 The World Bank Group. I would like to thank Taye Mengestae and Ali Mansoor for comments on an earlier draft and Warrick Smith and R. Shyam Khemani for helpful discussions during this project. This paper has not undergone the review accorded to official World Bank publications. The findings, interpretations, and conclusions expressed herein are those of the author and do not necessarily reflect the views of the International Bank for Reconstruction and Development / The World Bank and its affiliated organizations, or those of the Executive Directors of The World Bank or the governments they represent. The World Bank does not guarantee the accuracy of the data included in this work.

Senior Economist, Development Research Group - Competition Policy and Regulation, World Bank, MSN MC3-300, 1818 H Street, NW, Washington, DC 20433. Fax: 202-522-1155. Tel: 202-473-7454. Email: gclarke@worldbank.org. 


\begin{abstract}
Previous work has shown that firms in low and middle-income countries in Eastern Europe and Central Asia that feel greater pressure to innovate from their competitors are more likely to introduce new products and services than firms do not (Carlin et al., 2001; World Bank, 2004). However, competition also appears to affect innovation in other ways. In particular, firms in these countries that face greater price competition appear to be less likely to innovate than other firms (Carlin et al., 2001). The goal of this paper is to assess how competition and trade policy affect these different aspects of competition and, consequently, to assess their net impact on innovation. The paper finds that reducing tariffs and enacting and enforcing competition laws modestly increases both the pressure that firms feel regarding innovation and the level of price competition in the domestic economy. The net impact that lower tariffs have on new product and process development appears to be negative but small - for the most part the opposing effects cancel out. In contrast, stricter competition laws and better enforcement of those laws appear to increase the likelihood of new product and process development, especially when competition is treated as endogenous to innovation.
\end{abstract}




\section{INTRODUCTION}

Whether competition policy affects new product development and the introduction of new production processes in low and middle-income countries will depend upon at least two things. First, it will depend upon the effect of competition policy on competition in these countries. If competition laws are poorly enforced or competition policy is heavily politicized, they might have a minor, or even a negative, impact on competition. Second, it depends upon the effect of competition on innovation. Although enterprises in competitive sectors will generally have stronger incentives to introduce new products and reduce the cost of producing existing products, competition affects the resources that they have to invest in innovative activities. The goal of this paper is to empirically assess the impact of competition policy on innovation in low and middle-income countries using enterprise-level data from 27 low and middle-income countries in Europe and Central Asia.

The first issue is how much do different aspects of competition policy-trade policy, regulatory barriers to entry and competition law-affect competition in low and middle-income countries. Trade policy is perhaps the least controversial; there seems to be a relatively strong consensus that trade liberalization increases competition. ${ }^{1}$ For regulatory barriers to entry, there is considerably less empirical evidence — although results from some studies suggest that it might be important. In contrast, the effectiveness of competition, or anti-trust, law is controversial, even in industrialized economies. Based upon a survey of existing work and some new empirical work on the effect of mergers on price markups, Crandall and Winston (2003, p. 4) conclude that there is "little empirical evidence that past [anti-trust policy] interventions have provided much direct benefit to consumers or significantly deterred anti-competitive behavior' in the United States. ${ }^{2}$ Competition law is even more controversial in low and middle-income countries, where it is perceived to be less effective than it is in industrialized economies. For example, in a recent survey that asked enterprise managers about the effectiveness of anti-monopoly policy in their

\footnotetext{
${ }^{1}$ Tybout (2003) and World Bank (2002) summarize this literature.

2 Other studies, however, have questioned their conclusions. See Werden (2004) and Baker (2003).
} 
country, managers in low and middle-income countries were less likely to report that they believed it was effective. ${ }^{3}$

In addition to depending upon how competition policy affects competition, the impact will also depend upon how competition affects new product and process development. On the one hand, competition might increase the incentives that firms have to introduce new products and processes - if they fail to keep up, they will quickly find themselves overtaken by nimbler competitors. On the other, firms that face less competition might be able to use their market power to generate the resources that they need to finance new product and process development. In low and middle-income countries with poorly developed financial sectors, these resources might be especially important.

Previous work has shown that firms in low and middle-income countries in Eastern Europe and Central Asia that feel greater pressure to innovate from their competitors are more likely to introduce new products and services than firms do not (Carlin et al., 2001; World Bank, 2004). However, competition also appears to affect innovation in other ways. In particular, firms in these countries that face greater price competition appear to be less likely to innovate than other firms (Carlin et al., 2001). The paper's goal is to extend the current literature by assessing how competition and trade policy affect these different aspects of competition and, consequently, to assess their net impact on new product and process development in low and middle-income countries. First, it looks at how trade and competition policy affect these two aspects of competition. It then uses these estimates to assess the net impact of competition and tariff policy on innovation. It concludes that if trade policy has any effect on innovation, it is relatively modest. However, there is some evidence that competition law and policy might have a more significant impact.

\footnotetext{
${ }^{3}$ The survey asked managers to give a score on a 7-point scale, where 1 means 'lax and not effective at promoting competition' and 7 means 'effective and promotes competition'. In 2003, the average score in low-income countries was 3.1, the average score in lower middle-income countries was 3.4, the average score in upper middle-income countries was 3.6 and the average score in high-income OECD countries was 5.1(Porter et al., 2004).
} 


\section{Competition, Competition Policy ANd InNovation}

\section{II.1 The impact of policy on competition in low and middle-income countries}

Many government policies affect competition. One of the most direct ways that policy affects competition is through competition law. Although the goals, approach and scope of competition law vary between jurisdictions, the primary goal of most of these laws is to maintain and encourage competition and to prevent firms from gaining control of markets. Competition laws often include provisions intended to: ${ }^{4}$

- Prevent firms in the same industry from colluding or forming cartels. Prohibited actions include price-fixing agreements, collusion during tenders, and agreements to allocate markets.

- Prevent single dominant firms from exercising market power. Prohibited actions include predatory pricing, forcing firms that buy particular goods or services to also buy other goods or services, and setting discriminatory prices or terms of service.

- Require firms to notify the competition agency about horizontal mergers between firms in the same industry and vertical mergers between firms and their suppliers or distributorsand allowing the agency to investigate and prohibit mergers.

Competition laws have become increasingly popular in recent years. According to one recent study, around 100 countries now have competition (or antitrust) laws to address behavior of this kind-38 of these enacted laws for the first time or significantly strengthened existing competition legislation in the 1990s (Evenett, 2003). The transition economies of Eastern Europe and Central Asia were among the most enthusiastic adopters. By 1999, all of the transition economies except Bosnia and Herzegovina and Turkmenistan had at least drafted competition laws (Dutz and Vagliasindi, 2000; Vagliasindi and Campbell, 2004).

Overall, the empirical literature on the effect that competition law has on competition yields mixed results. A cross-country study of competition law in 42 developed and developing countries

\footnotetext{
4 These are based upon the recommendations in United Nations Conference on Trade and Development (2003). Also see Evenett (2003).
} 
found little evidence that competition law had a direct effect on prices; price markups were no lower in countries with competition laws in place than they were in other countries (Kee and Hoekman, 2003). However, a second study that looked at the impact of competition policy in Eastern Europe and Central Asia concluded that enterprises were more likely to have competitors in countries where competition law was stronger and better enforced (Vagliasindi, 2001). One difference between these two papers, other than the choice of dependent variable, is that whereas the first simply uses a dummy variable indicating whether the country had a law or not, the second uses a broader measure that takes implementation into account.

There are several reasons why competition law might be ineffective, especially in low and middle-income countries. One is that the agencies that enforce the laws in developing economies typically have fewer administrative and financial resources than agencies in industrialized economies. This is especially true in low-income countries. For example, in 2000, the competition authority in Tanzania had only two economists and no lawyers, while the authority in Zambia had four economists and one lawyer (CUTS Center for Competition, 2003).

A second problem is that it can be difficult to prosecute politically connected firms. For example, when the independent Monopoly Control Authority in Pakistan tried to take actions to reduce cartelization in the cement and vanaspati ghee markets, the government intervened, fixing prices at a 'mutually acceptable' level (CUTS Center for Competition, 2003). Similarly, when the competition authority in Tanzania forbade Tanzania Breweries from barring independent agents and mini-wholesalers from stocking competitors' products, the company, with support of some government officials, contravened the agency's orders (Economic and Social Research Foundation (ESRF), 2002). When government officials intervene against agency decisions on behalf of politically connected firms, competition agencies will be hesitant to move against these firms in the first place. This can be especially problematic in low and middle-income countries, which typically have weak institutional environments. Unless the agency can rely upon the judiciary to support its decisions and protect it against political intervention, the agency will find it difficult to enforce its rulings even if it is formally independent.

Competition law is not the only type of government policy that affects competition. Whereas competition law is generally intended to prevent firms from gaining control of markets, 
other government policies reduce competition. One notable way that governments reduce competition is by restricting access to foreign goods in the domestic market. Tariff and nontariff barriers make it more costly for foreign firms to enter domestic markets and consequently reduce the competitive pressure on domestic firms.

Many studies have found results that are consistent with the idea that trade restrictions reduce competition. ${ }^{5}$ Hoekman et al. (2001) conclude, based upon a cross-country analysis of 41 developed and developing countries, that average price markups are lower in countries with greater import penetration. Kee and Hoekman (2003) reach a similar conclusion. Country-level studies also support the hypothesis that imports put competitive pressure on domestic firms. Based upon a series of country case studies looking at Chile between 1979 and 1986, Colombia between 1977 and 1985, Mexico between 1985 and 1990, Morocco between 1984 and 1989 and Turkey between 1976 and 1985, Roberts and Tybout (1996) conclude that foreign competition resulted in reduced price mark-ups in every country in their study. Similarly, Harrison (1994) and Levinsohn (1993) show that trade liberalization reduced price markups in Côte d'Ivoire and Turkey respectively.

Another way that governments affect competition is by restricting entry. In some cases, for example when governments award legal monopolies, entry is simply prohibited. In other cases, the high fixed cost of meeting regulatory requirements can reduce competition by making it difficult for new firms to enter. The cost of business registration is high in many low and middle-income countries, including in many countries in Eastern Europe and Central Asia. Whereas it takes only about 31 days and costs only about 10 percent of per capita GNI to register a business in high-income OECD countries, it takes 48 days and cost 22 percent of GNI in Eastern Europe and Central Asia (World Bank, 2003). ${ }^{6}$

These barriers can reduce entry rates, and thus competition, significantly. A recent study found that entry rates for new enterprises in several middle-income countries - none of whom had exceptionally high costs by developing country standards - would increase by as much as 20

\footnotetext{
${ }^{5}$ This literature is summarized in Tybout (2003).

${ }^{6}$ Costs are calculated for a standard enterprise (e.g., in terms of size and sector) across countries in January 2003.
} 
percent if they reduced the cost of registering a business to the cost of doing so in the United States (Bartelsman et al., 2004). ${ }^{7}$ To the extent that these barriers discourage entry, they will also reduce competition.

\section{II.2 The impact of competition on innovation in low and middle income countries}

In addition to depending upon the effectiveness of government policy in promoting competition, the effect of competition policy on innovation will depend upon the complex relationship between competition and innovation. Theoretical models do not unambiguously predict whether competition should encourage or discourage innovation, with different models predicting opposite effects. Perhaps the most common view of the relationship is that competition is likely to encourage innovation. For example, Adam Smith (1776, cited in Nickell, 1996) argued "monopoly... is a great enemy to good management" and Hicks (1935) argued that one of the main benefits of monopoly is that it allowed companies to enjoy a quiet life. If firms in competitive industries fail to introduce new products or new technologies that reduce costs, nimbler competitors will quickly force them out of the market. In contrast, firms with market power-especially those protected by government laws or regulations that make entry difficult and those that can protect their position by engaging in anticompetitive behavior - might not face the same risks if they fail to innovate.

Theoretical models that formalize these ideas often rely upon the concept of 'managerial slack.' Rather than simply maximizing profits, managers also want to minimize effort. Although enterprise owners want to stop managers from slacking, this might be easier in competitive industries since owners can compare the enterprise's performance with the performance of its competitors in these industries (Nickell, 1996). These ideas have been formalized in several theoretical models. For example, in a model with both managers whose goal is to minimize effort without going out of business (i.e., 'satisficing' managers) and profit-maximizing managers, Aghion et al. (1999) show that product market competition can encourage innovation.

\footnotetext{
7 The countries were Brazil, Chile, Colombia, Hungary, Latvia, Mexico, Romania, Slovenia, and Venezuela. Increases exceeded 10 percent in Brazil, Chile, and Mexico and exceeded 20 percent in Colombia, Hungary, and Venezuela.
} 
This is not the only way, however, that competition might affect innovation. A second common view is the 'Schumpeterian' view that firms will only innovate if they are able to recoup the cost of innovation through the capture of monopoly rents. Indeed, this is the goal of patent protection; patents create temporary monopolies that allow innovating firms to exploit their ideas without having to compete with competitors who otherwise would be able be able to expropriate their ideas. Without the creation of the temporary monopoly, firms might be unwilling to invest resources in research and development. In summary, firms that face strong competition might have little reason to invest in new product or process development since if they do innovate, their competitors will quickly copy their ideas, dissipating rents and preventing the innovating firm from recouping its investment.

These arguments might be particularly important in developing countries. In addition to having a greater incentive to invest in innovative activities, firms with market power will also have greater ability to do so. Even when firms are not introducing entirely new technologies or products, copying and adapting existing technologies can be costly, especially when the adapting firms is less technological developed than the market leader. ${ }^{8}$ Consequently, to the extent that firms with market power have more stable (and larger) cash flows and face less market uncertainty, they will find it easier to invest in new products and processes (Nickell, 1996). In low and middle-income countries with underdeveloped financial markets, firms have to rely upon retained earnings for investment, making these arguments especially important.

Although the previous arguments suggest that competition in the market might discourage innovation, a different type of competition-competition for the market-might encourage innovation. When firms can use patents - or other mechanisms - to protect new innovations, innovations allow firms to either gain market power or lower their costs relative to their rivals. Under these circumstances, competition for the market might increase innovation as

\footnotetext{
${ }^{8}$ Mansfield et al. (1981) finds that, on average, it cost imitating firms $65 \%$ of the cost of innovation to imitate new products. In one seventh of the cases, imitation costs were at least as high as innovation costs. Mansfield et al. (1981) note 'this was not due to any superiority of the imitative product over the innovation. Instead, in a substantial percentage of these cases, it was due to the innovator having a technological edge over its rivals in the relevant field.' They also found that although patents increased the cost of imitation, the median estimated increase was only $11 \%$.
} 
firms try to quickly develop and patent new ideas before their rivals do. ${ }^{9}$ Although early work suggested that innovation will be faster when more participants are competing for the market (Dasgupta and Stiglitz, 1980), more recent work has suggested that the effect of increased competition will depend upon a variety of factors including the nature of the innovation (i.e., whether innovation leads to large or small cost reductions) and the intensity of competition in the market. ${ }^{10}$

Because these arguments rely upon innovating firms being able to protect their intellectual property, a natural question is whether this is likely to be the case for the mostly small and medium-sized enterprises from low and middle-income countries covered in this paper. Many of the new products and processes introduced by firms in these countries are likely to be new to the firm rather than new to the market. Given the relatively low number of patents issued to firms in Eastern Europe and Central Asia (see Table 1), it seems plausible that few of the products and processes introduced by the mostly small and medium-sized enterprises will be covered by patents (i.e., there will be less of a distinction between competition for the market and competition in the market). A second point is that research and development might not be as important for these firms with respect to the introduction of new products and processes in these countries as it would be for firms in high-income countries. For example, in a recent survey of enterprises in Serbia and Montenegro, only 10 percent said that the most important way that they acquired technological innovations was developing or adapting them internally. ${ }^{11}$ The most popular way of acquiring new technologies (36 percent of enterprises) was through purchasing new machinery and equipment.

Several recent studies have looked at the impact of competition on labor and total factor productivity in the transition economies. A recent meta-analysis of results from these studies concluded that competition generally results in improved productivity (Djankov and Murrell, 2002). In general, they find that results tend to stronger for domestic competition than for

\footnotetext{
${ }^{9}$ See, for example, Aghion et al. (1999) and Aghion et al (2001).

${ }^{10}$ Encaoua and Hollander (2002) summarize this literature.

${ }^{11}$ Data is from the Investment Climate Survey for Serbia and Montenegro in 2003 @ The World Bank Group. This question was not asked in the 2002 BEEPS Survey.
} 
competition from imports and tend to be stronger for countries in Eastern Europe than for countries in the Commonwealth of Independent States. In fact, they find that competition from imports has a negative, although statistically insignificant impact, in the Commonwealth of Independent States. $^{12}$

Although these results are consistent with the idea that competition encourages innovation, productivity improvements are not necessarily the result of innovation. For example, improvements could be due to increased effort (e.g., by management) without the introduction of new products or production technologies. Consistent with this idea, recent studies that have looked at the effect of competition on new product and process development suggest a more nuanced picture. On the one hand, pressure from other firms to develop new products, services and markets appears to be important. Firms that felt greater pressure, especially from foreign firms, were more likely to introduce new products or to use new production technologies than firms that felt less pressure (Carlin et al., 2001; World Bank, 2004). However, Carlin et al. (2001) also found that firms with greater market power were more likely to innovate. Thus, competition does not appear to have an unambiguous effect on innovation in low- and middleincome countries.

\section{EMPIRICAL METHODS AND RESULTS}

\section{III.1 Data}

The data used in this study are from the 2002 Business Environment and Enterprise Performance Survey II (BEEPS II), an enterprise-level survey that covered 27 countries in Eastern Europe and Central Asia. ${ }^{13}$ MEMRB Custom Research Worldwide conducted the survey on behalf of the European Bank for Reconstruction and Development and the World

\footnotetext{
12 Using data from five countries in Eastern Europe and Central Asia, Bastos and Nasir (2004) conclude that competition has a greater affect on productivity than the quality of infrastructure, corruption or bureaucratic burden.

13 The BEEPS II survey is described in greater detail in Fries et al. (2003) and Hellman and Kaufmann (2002). The countries are Albania, Armenia, Azerbaijan, Belarus, Bosnia and Herzegovina, Bulgaria, Croatia, the Czech Republic, Estonia, FYR Macedonia, Georgia, Hungary, Kazakhstan, the Kyrgyz Republic, Latvia, Lithuania, Moldova, Poland, Romania, Russia, Serbia and Montenegro, the Slovak Republic, Slovenia, Tajikistan, Turkey, Ukraine, and Uzbekistan. The survey covered all countries in the region in which the EBRD operates, other than Turkmenistan.
} 
Bank. MEMRB followed the ICC/ESOMAR International Code of Marketing and Social Research Practice. Enterprises participating in the survey were assured that their identities would not be disclosed to the government. Enumerators interviewed firm managers in a uniform way across countries in face-to-face meetings.

The sampling frame was constructed to be broadly representative of enterprises within each country in terms of sector, size and geographic location. Certain firms were excluded from the survey. These included firms in sectors that were subject to government price and prudential regulations (e.g., utilities and banks) and in the agricultural sector, firms with fewer than two employees or more than 10,000 employees, and firms that were less than three years old. The final restriction was imposed because some questions (e.g., on business performance) covered the period 1999 to 2001 . In addition, at least 10 percent of enterprises were required to be in the following categories: small (less than 50 employees), medium (50 to 249 employees) and large (more than 250 employees), foreign controlled, state-controlled, exporters and from small cities (under 50,000 people) or rural areas.

The survey included enterprises in services, manufacturing, construction, and mining and quarrying. Since this paper is interested in the effect of both trade policy and competition policy, the sample in this paper only includes manufacturing firms. The data from BEEPS II are supplemented with additional data collected by the World Bank and the European Bank for Reconstruction and Development. Tariff data is obtained from the UNCTAD TRAINS database. Table 2 presents summary statistics for the main variables included in the empirical analysis.

\section{III.2 Econometric Approach}

To address the first question - the effect that competition policy and trade policy have on competition - we estimate the following equation:

$$
\text { Competition Index }{ }_{i j k}=\delta_{1} \text { tariff }_{j k}+\partial_{2} \text { competition policy }_{j}+\beta x_{i j k}+\gamma z_{j}+\lambda_{j}+\eta_{k}+\varepsilon_{i j k}
$$

The competition indices represent the amount of competition that firm $i$ in country $j$ and sector $k$ faces. Higher values on the indices represent higher levels of competition. The three indices that are analyzed are: 
- Index of Domestic Price Competition. This index represents that amount of domestic sales that the enterprise manager believes the firm would lose if it raised prices by 10 percent in real terms while its competitors did not. A "1" on this 4-point scale means that the manager believes that the firm would not lose any sales, while a "4" means that the manager believes that many of its customers would buy from its competitors instead.

- Index of importance of pressure from foreign competitors on decisions concerning new products, services and markets. This index represents the importance of foreign competitors on decisions with respect to development of new products, services and markets. A "1" on the 4-point scale means that pressure from this source is "not at all important', while a "4" means that it is very important.

- Index of importance of pressure from domestic competitors on decisions concerning new products, services and markets. As above, but for pressure from domestic competitors.

We focus on these indices because (i) we would generally expect competition policy to have a direct effect on each of these measures of competition and (ii) previous work has shown that they are associated with innovation (Carlin et al., 2001; World Bank, 2004).

The indices are limited dependent variables that take four distinct values. Since the numbers are ordered rankings (with higher values indicating greater competition), but are not count data, the regressions are estimated as ordered probit regressions (i.e., it is assumed that the error term, $\varepsilon_{\mathrm{ijk}}$, has a normal distribution). One concern is that error terms might be correlated for enterprises within the same country. Since this can result in the standard errors appearing to be artificially small, it might inflate the t-statistics especially on country level variables (Moulton, 1986). To control for this, results are presented using Huber-White standard errors, allowing error terms to be correlated within countries (i.e., with 'clustered' standard errors). ${ }^{14}$

The main variables of interest are the tariff rate, tariff $f_{k}$, and measures of competition policy, competition policy. The tariff rate is the average tariff rate for industry $\mathrm{j}$, defined at the 4-figure ISIC level, in country k. Unfortunately, comparable information was not available to

\footnotetext{
${ }^{14}$ See Huber (1967) and Rogers (1993).
} 
calculate more sophisticated measures of trade protection (e.g., effective protection rates or measures that incorporate non-tariff barriers).

Several measures of competition policy are used in the empirical analysis. The first measure is an index that represents how strict merger notification laws are in the country. The index is based upon the measure of merger notification requirements described in Nicholson (2003), with higher values representing stricter laws. ${ }^{15}$ The measure of 'barriers to entry' is the number of days to register a standardized business (World Bank, 2003). In addition to these two variables, another measure of competition policy is included in some model specifications as a robustness check. The competition policy index, which represents both competition law and barriers to entry, is taken from European Bank for Reconstruction and Development (2003) In contrast to the previous measures of competition policy, which are based upon legal requirements, this measure takes enforcement into account. One concern about it, however, is that although it is based partly upon objective criteria (i.e., whether competition legislation is in place), it is partially subjective (e.g., the difference between a ' 3 ' and a ' 4 ' is based on the difference between 'some enforcement' and 'significant enforcement'). ${ }^{16}$ This might be problematic if the actual level of competition in the economy affects experts' perceptions about competition policy. Since the competition policy variables are not available at the industry level and, therefore, are defined at the country level, they have to be omitted in the regressions that include country dummies.

In addition to the main variables of interest, the analysis includes a series of country $\left(\lambda_{\mathrm{j}}\right)$ and sector dummies $\left(\gamma_{\mathrm{k}}\right)$. The country dummies are included to control for unobserved differences between countries that affect the level of competition in the country. For example, competition from imports might be less in poor countries or in countries with higher natural barriers to trade (e.g., countries that are more remote). If these characteristics were correlated with the policy variables, the coefficients on the policy variables might be biased. In some

\footnotetext{
15 The index is coded as " 0 " if the country has no merger notification law, coded as " 1 " if merger notification is voluntary, coded as " 2 " if post-merger notification is mandatory, and " 3 " if pre-merger notification is mandatory. Information on notification laws was obtained from White and Case (2004)

${ }^{16}$ For example, the 2003 Transition report states ' $[t]$ he classification system is a stylized reflection of the judgment of the EBRD's Office of the Chief Economist.' See European Bank for Reconstruction and Development(2003).
} 
regressions, the country dummies are replaced with a small set of country controls $\left(\mathrm{z}_{\mathrm{j}}\right)$. Because we have data from only 27 countries, only a relatively modest number of country controls can be included. The country level controls are per capita GDP, size and population (to proxy for natural barriers to trade) and a dummy for countries in the Commonwealth of Independent States (as a proxy for remoteness). Because the country dummies control for country differences more completely than the country controls, these results are generally preferable for variables such as tariff levels that are not defined at the country level. Sector dummies - also at the 4-figure ISIC level - are included to control for sector characteristics that might affect the level of competition in the sector. For example, sectors characterized by greater economies of scale might be less competitive than other sectors.

In addition to these variables, the regressions also include a series of enterprise-level controls $\left(\mathrm{x}_{\mathrm{ijk}}\right)$. These controls include number of workers (as a proxy for size), dummies indicating that the firm is partly foreign-owned, partly government owned or a de novo private enterprise (as opposed to a privatized enterprise), and a dummy indicating that the enterprise is an exporter.

\section{III.3 Econometric Results}

Average Tariff Rate. Enterprises were more likely to report that they would lose domestic sales to their competitors if they raised domestic prices by 10 percent and their competitors did not in countries where tariffs are lower. The coefficient on average tariff rates in the sector is statistically significant and negative whether country dummies or country controls are included in the regression and whether the EBRD competition policy index or the merger notification law index and days to register a business are used as controls for competition policy (see columns 1, 2 and 3 of Table 3). As noted previously, the regressions include a set of sector dummies, also at the 4-figure ISIC industry level, to control for sector differences that might affect competition (e.g., related to economies of scale that might affect the level of competition in the sector).

The parameter estimates suggest that tariff rates have a relatively modest impact on domestic price competition. If tariffs were set at the median level for the sample for all goods (10.5 percent), the average estimated score on the competition index would be 2.62 and the 
average probability that an enterprise would report that many of its customers would buy from its competitors if it raised prices by 10 percent would be 28.9 percent. ${ }^{17}$ If tariffs were uniformly set at level of the $80^{\text {th }}$ percentile (18.3 percent), the average score would be 2.54 and the average probability would be 26.2 percent. If tariffs were uniformly set at the level of the $20^{\text {th }}$ percentile ( 5 percent), the average score would be 2.67 and the average probability would be 30.9 percent. Increasing a uniform tariff from 5 percent to 18.3 percent would therefore reduce the probability that the average enterprise would lose many of its customers if it raised prices by 4.7 percentage points - about a 15 percent reduction.

Tariffs also appear to affect pressure from foreign competitors. Enterprises were less likely to feel that pressure from foreign competitors had an important influence on their decisions to develop new products, services or markets in countries where tariffs were higher. The coefficient on the average tariff rate was statistically significant and negative whether country dummies or country controls and the EBRD competition policy index were included in the regression (see columns 5 and 6 of Table 3). Although the coefficient becomes statistically insignificant when the merger notification law index and days to register a business are included instead of the EBRD competition policy index, these measures will control for country differences less well than the country dummies would. Overall these results suggest that firms feel less pressure from foreign firms in sectors and countries where tariff protection is high.

The impact is slightly smaller than the impact on domestic price competition. If tariffs were set at a uniform 10.5 percent (the sample median), the average score on the index of pressure from foreign firms would be 2.36 and the average probability that a sample firm would rate pressure from foreign firms as an important influence on decisions regarding development of new products and services is 21.1 percent. If tariffs were set at a uniform level of 5 percent (the $20^{\text {th }}$ percentile), the average score would be 2.38 and the average probability would be 21.8 percent. If tariffs were set at a uniform level of 18.3 percent (the $80^{\text {th }}$ percentile), the average score would be 2.32 and the average probability would be 19.2 percent. Hence, increasing a

\footnotetext{
${ }^{17}$ The average probabilities are calculated using the coefficients from Table 3, column 1. For each enterprise in the sample, the probability that the enterprise would report that many customers would buy from their competitors instead if they increased prices by 10 percent is calculated replacing the actual tariff rate for that sector and country by the sample median, the $80^{\text {th }}$ percentile tariff rate, or the $20^{\text {th }}$ percentile tariff rate.
} 
uniform tariff from 5 percent to 18.3 percent would decrease the probability that the average enterprise would see pressure from foreign firms as an important influence by 2.6 percentage points—a 14 percent decrease.

Not surprisingly, tariffs do not appear to have a significant impact on the pressure that firms feel from domestic firms. The coefficient on average tariff rate is statistically insignificant in analogous regressions for pressure from domestic enterprises (see columns 7-9).

Competition law and barriers to entry. Enterprises were also more likely to report that they would lose customers to competitors if they raised domestic prices by 10 percent and their competitors did not in countries with stricter competition laws (see Column 1). The coefficient on the merger notification index is positive and statistically significant in the regression for the price competition index. In contrast, the coefficient on days to register a new business is consistently statistically insignificant in all three regressions. The effect of having a merger notification law appears relatively large. The average score on the price competition index would be 2.56 in countries with laws that require pre-merger notification compared to 2.24 in countries with no merger notification requirements. Similarly, the average probability that an enterprise would say it would lose many of its customers if it raised prices is 17.5 percent in countries with no law, compared to 26.9 percent in countries with a pre-merger notification requirement.

Results are similar when the merger notification law index is replaced with the competition policy index. As noted previously, the competition policy index rates barriers to entry as well as competition law and, therefore, the variable for days to register a new business is omitted in these regressions. The coefficient on the index of competition policy is also positive and statistically significant (see column 2 of Table 3). The parameter estimates suggest that competition policy also has a reasonably modest impact on domestic price competition. If the index were set at the level of the $20^{\text {th }}$ percentile (2.0), the average score would be 2.55 and the average probability would be 26.4 percent. If it were set at the level of the $80^{\text {th }}$ percentile (2.7), the average score would be 2.66 and the average probability would be 30.2 percent. Increasing the quality of competition policy from the level observed in Georgia or Russia (2.0) to the level observed in Estonia or Slovenia (2.7) would increase the average probability that an enterprise 
would expect to lose many customers to its competitors if it raised prices by 10 percent by 3.8 percentage points - about a 14 percent increase.

While tariff rates would only seem to affect the amount of pressure that firms feel from foreign competitors, competition policy might affect the pressure that firms feel from both foreign and domestic enterprises. For example, a dominant firm that is able to maintain its position through marketing restrictions or control over distribution might be able to effectively prevent competition from both domestic firms and imports.

In the regression for pressure from foreign firms, the coefficient on the merger notification index is positive and statistically significant. This is consistent with the idea that pressure from foreign firms is greater in countries with stricter merger notification laws. The effect is, once again, reasonably large. The average score on the index for pressure from foreign firms would be 2.08 if all countries had no notification requirements and 2.37 if all countries had pre-merger requirements.

Although the coefficient on the merger notification index is positive in the regression for pressure from domestic firms, it is statistically insignificant at conventional significance levels (see column 7). However, the coefficient on the competition policy index is statistically significant at a 5 percent level in the regression for the importance of pressure from domestic firms (see column 8 of Table 3). Increasing the competition policy index from 2.0 to 2.7 increases the probability that the average firm would rate pressure from domestic firms as very important from 22.9 percent to 28.2 percent - a 5.3 percentage point or 23 percent increase - and the average score on the index from 2.66 to 2.82 .

Other enterprise-level controls. For the most part, the coefficients on the enterprise-level controls are statistically insignificant at conventional significance levels. For example, in the regression for the index of domestic price competition, the coefficients were statistically insignificant on all variables except for the dummy variable indicating that the firm is an exporter.

There were some exceptions to this rule, however. Large firms were more likely to say that pressure from foreign firms was important with respect to developing new products and 
services, but not more likely to report that domestic price competition was greater nor to report that pressure from domestic firms was important. Firms that were at least partially foreign-owned were less likely to report pressure from domestic competitors was important, as were firms that were at least partially state-owned. Finally de novo private firms were less likely to report that pressure from domestic enterprises was important.

Firms that export tend to feel less competitive pressure than other firms - at least in domestic markets. They were less likely to report that they would lose customers in domestic markets if they raised prices than non-exporters were. They were also less likely to report that they felt that pressure from domestic firms had an important effect on their decisions to develop new products, services or markets. It is important to note that most exporters sell a significant portion of their output on domestic markets. The median exporter exported only about 35 percent of output and only 9 percent of exporters ( 5 percent of firms) exported all their output. Because exporters tend to be more efficient and technologically advanced than domestic firms that do not export, it might not be surprising they generally feel less pressure from other domestic enterprises than non-exporters do. In contrast to the previous results, exporters were more likely to report pressure from foreign firms than non-exporters were. Given that exporters are likely to compete with foreign firms in both domestic and international markets, this is not surprising.

Other macroeconomic controls. The country level controls were generally statistically insignificant in the regressions for pressure from domestic firms to develop new products and services and for the index of domestic price competition. In contrast, the coefficients on most of these variables were statistically significant in the regression for pressure from foreign firms. Pressure from foreign firms was more important in countries with greater population, smaller area, higher per capita GDP and that are in the Commonwealth of Independent States. The coefficients on the $\log$ of population and the $\log$ or area have opposite signs but are very close in terms of absolute magnitude. This suggests that pressure from foreign firms regarding development of new products and processes is more important in countries that are more densely populated. One plausible explanation for this is that small densely populated countries are more naturally open than larger, less densely populated countries. Consistent with the idea that pressure from foreign firms is more important in countries that are more naturally open, pressure 
from foreign firms is also less important in countries in the Commonwealth of Independent States. Countries in this region will tend to be further from Western European markets than countries in Central and Eastern Europe. Pressure from foreign firms tends to also be more important in countries with higher per capita GDP. These last two results are not robust to including the objective measures of competition policy in place of the competition policy index.

\section{III.4 Impact on Innovation}

The previous results suggest that competition policy does indeed have a positive impact on competition in the low and middle-income countries of Eastern Europe and Central Asia. Competition law - and possibly barriers to entry — appears to affect both price competition and the pressure that firms feel to develop new products and services. Similarly tariffs appear to affect price competition and pressure from foreign firms regarding new products and services.

A natural question is whether this increased pressure increases the likelihood that firms introduce new products and processes. As noted earlier, although previous research has found that firms are more likely to innovate when they feel pressure from competitors (Carlin et al., 2001; World Bank, 2004), price competition appears to have the opposite effect (Carlin et al., 2001). The net impact of competition policy will therefore depend upon the magnitude of the effect that competition policy has on price competition and pressure from competitors as well as the magnitude of the effect of price competition and pressure from competitors on innovation.

\section{III.4.1 Estimation}

To estimate the impact that pressure from foreign and domestic firms and price competition have on innovation, two dummy variables indicating whether between 1998 and 2001 the firm (i) introduced a major new product line and (ii) introduced a new technology that substantially changed the way it produces its main product are regressed on the competition indices from the previous section and a series on control variables.

$$
\text { Innovation }_{i j k}=\delta_{1} \text { competition indices }_{i j k}+\beta x_{i j k}+z_{j}+\lambda_{j}+\eta_{k}+\varepsilon_{i j k}
$$

Since the dependent variables are dummy variables, the model is estimated using probit estimation. The coefficients presented in the tables are marginal effects for continuous 
independent variables (including the competition indices) and are the effect of switching the dummy from " 0 " to " 1 " for discrete dummy variables. These effects are calculated at sample means for all variables.

One concern is that the competition indices tend to be highly correlated. The correlation between the two indices indicating pressure from foreign and domestic firms is 0.14 (pvalue $=0.00$ ) and the correlations between the measure of price competition and the two indices for pressure from foreign and domestic firms are $0.19(\mathrm{p}$-value $=0.00)$ and $0.09(\mathrm{p}$-value $=0.00)$ respectively. Because of concerns about multicollinearity, we use principal components analysis to construct a single index for pressure from foreign and domestic firms. As a robustness check, we also include the two separate indices for pressure from foreign and domestic firms simultaneously. Because past work has indicated that pressure to innovate and price competition affect firms' decisions regarding innovation differently, we do not attempt to merge all three indices into a single measure of competition. However, we do include the indices for price competition and pressure from foreign and domestic firms separately as additional robustness checks.

The control variables include a series of enterprise-level controls, a series of sector dummies (at the 4-figure ISIC level), and a series of countries dummies. As before, to control for the possibility that error terms might be correlated for enterprises within the same country, 'clustered' standard errors are presented.

A concern in this part of the analysis is that the competition indices might be endogenous. This is a particular concern for the index for price competition-firms that are particularly innovative might be able to reduce price competition by differentiating their products from those of their competitors. Hence, a negative correlation between price competition and innovation might be due to innovation reducing price competition rather than price competition reducing innovation. Therefore, as an additional robustness check, we treat the competition indices as endogenous, using the trade and competition policy variables as instruments. The policy variables would seem to be appropriate instruments in that we would expect competition policy to affect innovation primarily through its effect on competition. 


\section{III.4.2 Results}

Pressure from foreign and domestic enterprises. Consistent with earlier work, firms were more likely to introduce new production technologies and new product lines between 1998 and early 2002 when they felt greater pressure from foreign and domestic firms to innovate. The coefficient on the index indicating pressure to innovate from foreign and domestic competitors is positive and statistically significant at a 1 percent level or higher in the regressions for the introduction of both new production processes (see column 1 in Table 4) and new products (see column 1 in Table 5). The positive coefficients suggests that firms that perceive that they are facing greater competitive pressure from competitors to innovate are, indeed, more likely to introduce new technologies and production processes. These results are robust to including country dummies rather than country controls (see column 2) and to omitting the index for price competition (see column 3).

The results are also robust to including the two indices for pressure from foreign and domestic firms simultaneously rather than the first principal component. The coefficients on both indices are positive and statistically significant at a 10 percent level or higher (see column 6). Although the point estimate of the coefficient on the index for pressure from foreign firms is larger and more highly statistically significant than the coefficient on the index for pressure from domestic firms, the coefficients are close in size. In fact, tests of the null hypotheses that the two coefficients are equal cannot be rejected in either regression. ${ }^{18}$ Likelihood ratio tests fail to reject the model with the first principal component of the two indices in favor of the model with the two indices included separately. ${ }^{19}$

The impact of this pressure appears to be quite large. The estimate of the marginal effect (estimated at sample means) is 0.05 in the regression for new process development and 0.07 in the regression for new product development. This suggests that increasing the index for foreign firms by 1 point (on a four-point scale) would increase the probability that a firm introduced a

\footnotetext{
${ }^{18}$ The $\chi^{2}(1)=0.25$ [p-value $\left.=0.61\right]$ and $\chi^{2}(1)=0.36$ [p-value $\left.=0.55\right]$ for new production technologies and new product lines respectively.

${ }^{19}$ The $\chi^{2}(1)=0.4$ and $\chi^{2}(1)=0.6$ for new production technologies and new product lines respectively.
} 
new production technology between 1998 and 2001 by about 5 percentage points and increases the probability that the firm developed a new product line by about 7 percentage points. ${ }^{20}$

Although this might suggest that trade and competition policy might have a large effect on decisions regarding new products and technologies, it is important to keep in mind that a 1point gain is much larger that the changes estimated in the previous section. Based upon the coefficients in the previous sections, decreasing tariffs from 18.3 percent to 5 percent (the $20^{\text {th }}$ percentile and $80^{\text {th }}$ percentile respectively) would increase the average score on the pressure from foreign competitors index by only about 0.06 points - and would have little effect on pressure from domestic firms. Thus, cutting tariffs by this amount would increase the index of pressure by only about $0.04 .^{21}$ Based upon the coefficients in this section, cutting tariffs by this amount would increase the probability that an average firm would develop a major new product by only about 0.2 percentage points and that it would introduce a new production technology by only about 0.3 percentage points. Similarly, enacting a law that required pre-merger notification would increase the likelihood that the average enterprise would introduce a new process by 1.0 percentage points and a major new product by 1.4 percentage points.

Price Competition. The coefficient on the index for domestic price competition is statistically significant and negative in the regressions for new production processes (see column 1 in Table 4) and new products (see column 1 in Table 5). In contrast to the previous results, this suggests that competition reduces the likelihood of a firm introducing new products and processes: firms that face greater price competition are less likely to introduce new products and production technologies. These results are also robust to including country dummies rather than country controls (see column 2). When the index for pressure to innovate is omitted, the coefficient on the index for price competition remains statistically significant in the regression for new production processes but not for new products (see column 4).

\footnotetext{
${ }^{20}$ Probabilities are estimated using the marginal changes calculated at the means for all variables.

21 The estimates from the principal component analysis indicate that a one-point increase on the foreign pressure index increases the principal component index by 0.62 points and a one-point increase on the domestic pressure index increases the principal component index by 0.68 points.
} 
Cutting tariffs from 18.3 percent to 5 percent (the $20^{\text {th }}$ percentile and $80^{\text {th }}$ percentile respectively) would increase the average score on the index by only about 0.13 points. Thus, the coefficients in this section suggest that this would decrease the probability that an average firm would introduce new products and production technologies by only about 0.8 and 0.4 percentage points respectively. Similarly introducing a pre-merger notification requirement would decrease the average probabilities by 1.9 and 1.0-percentage points respectively.

The net impact of changes in competition policy is, consequently, quite modestalthough usually negative. Since changes in competition increase both pressure from competitors to innovate and price competition, the net effect on new product and process development will be quite modest. Reducing tariffs from 18.3 percent to 5 percent would decrease the probability of new product and process development by 0.6 and 0.1 percentage points respectively. Introducing a pre-merger notification requirement would decrease the average probability of introducing a new process by 0.9 percentage points and increase the average probability of new product development by 0.5 percentage points. Improving the country's score on the competition policy index yields similar results. ${ }^{22}$

Other firm characteristics. Large firms were more likely to introduce new production technologies and develop new products and upgrade existing product than smaller firms were. The coefficient on this variable is statistically significant at a 5 percent level or higher in both regressions. Firms with any government ownership were about 9 percentage points less likely to upgrade production technologies and 16 percentage points less likely to develop new product lines. The coefficients on the dummy variable indicating that the firm was foreign-owned were statistically insignificant in all regressions.

De novo private firms and exporters were more likely to introduce new production techniques and new products. The coefficient on the de novo dummy variable was statistically significant and positive in both regressions. The coefficients on the dummy variable indicating the firm is an exporter were positive and statistically significant in both regressions. The point

\footnotetext{
22 Increasing the score on the competition policy index would decrease the average probability of new process development by 0.1 percentage points and increase the average probability of new product development by 0.5 percentage points.
} 
estimates of the coefficients suggest that exporters were 11 percentage points more likely to introduce new product lines and 6 percentage points more likely to introduce new production processes. The impact of being a de novo private firm (rather than a privatized firm) was also large. De novo private firms were 8 percentage points more likely to have introduced new production technologies and 15 percentage points more likely to develop new product lines.

\section{III.4.3 Robustness Checks}

Non-linear effect of competition. Previous work has suggested that changes in competition might have a non-linear effect on innovation (Carlin et al., 2001). In general, this study does not provide strong support for a non-linear effect. When squared terms are added to the base regression, the squared terms are singly and jointly statistically insignificant in the regression for the adoption of new production processes (see column 5 in Table 4). ${ }^{23}$ In the regression for new product development, the coefficient on the squared term for the price competition index is statistically insignificant. In contrast, the coefficient on the squared term for the index of pressure from competitors is statistically significant. However, the point estimates of the coefficients suggest that increases in pressure from competitors will increase the likelihood of innovation across almost all of the range of the index (between 0 and 4). Based upon the coefficient estimates, the turning point is at 3.4-close to the maximum of the range.

Additional measures of competition. The measures of competition used throughout the analysis are not the only possible measures of competition included in the BEEPS dataset. Two additional measures are the manager's estimate of his firm's market share in the domestic market and the manager's estimate of the number of competitors his firm faces in the domestic market. The results are generally robust to adding these measures to the regressions (see columns 1-2 and 4-5 in Table 6).

The coefficient on market share is statistically insignificant in the regression for both new process development and new product development. The coefficient on pressure from foreign

\footnotetext{
${ }^{23}$ As noted above, to ensure that the index for pressure from competitors is always positive, a constant (2) is added to the principal component index before it is squared. As a result the index varies between (just above) zero and (just below) four.
} 
and domestic competitors remains statistically significant and positive when this variable is added to the regression. The coefficient on domestic price competition remains negative and statistically significant in the regression for new process development and remains negative, but becomes statistically insignificant. for new product development. The coefficients on pressure from competitors and domestic price competition are slightly smaller in both regressions.

The coefficient on estimated number of competitors is statistically insignificant in the regression for new product development, but is statistically significant in the regression for new process development. However, including this variable does not affect the signs or statistical significance of the coefficients on the indices for pressure from competitors or domestic price competition.

Additional measures of pressure to innovate. The BEEPS II questionnaire also contains questions about the effect that pressure from government, creditors, shareholders and customers has on decisions to innovate. These other sources are linked less directly to competition than pressure from foreign and domestic competitors. However, responses to these questions tend to be highly correlated - firms that feel pressure to innovate from one source usually feel pressure from other sources. ${ }^{24}$ Including an additional variable representing other sources of pressure does not have a large effect on the previous results (see Table 6, columns 3 and 6). ${ }^{25}$ Coefficients on the indices for pressure from competitors and domestic price competition remain statistically significant, although the coefficient on pressure from domestic and foreign competitors becomes slightly smaller.

Endogeneity of the competition indices. As discussed above, there is some concern that product and process development might affect competition. For example, firms that are more innovative might be able to better differentiate their product from the products produced by potential competitors. Consequently, as a robustness check, we allow the level of competition to be determined endogenously. The instruments are the trade and competition policy variables

\footnotetext{
${ }^{24}$ The correlations vary between 0.06 and 0.37 and are statistically significant at greater than a 1 percent level in all cases.

25 The composite variable representing pressure from other sources is the first principle component combining the additional measures of pressure.
} 
from the previous section. Since these variables are correlated with the competition indices (see previous section) but should not affect innovation other than through their impact on competition, they would seem to be reasonable instruments. Since the dependent variable is a dummy variable, the probit equation is estimated using a procedure suggested by Newey (1987). ${ }^{26}$ Hypothesis tests of the null hypothesis that the competition variables are exogenous reject the null at a 10 percent significance level, favoring the results treating the variables as endogenous. $^{27}$

The results for the index of pressure from foreign and domestic competitors are robust to this change. The coefficients remain statistically significant and positive after allowing the index to be determined endogenously (see columns 2 and 4 of Table 7). Although the coefficient on the price competition index remains negative, it becomes statistically insignificant at conventional significance levels. Dropping the price competition index does not affect the results for the index of pressure from foreign and domestic competitors (see columns 1 and 3).

The coefficients are considerably larger when competition is treated as endogenous than when treated as exogenous. However, for tariffs at least the larger effects are mostly offsetting - if the coefficient on the index of price competition is assumed to be the point estimate (rather than zero). Based upon the point estimates of the coefficients in columns 2 and 4 of Table 7 (i.e., assuming that the coefficient on the index of price competition is not zero), reducing tariffs from 18.3 percent to 5 percent would increase the likelihood of new product development by 0.2 percentage points, but reduce the likelihood of new process development by 0.3 percentage points. Introducing a pre-merger notification would have a greater effectincreasing the probability of new product development by nearly six percentage points and increasing the probability of new process development by about four percentage points. Using

\footnotetext{
26 The procedure that we use is the IVTOBIT routine written for STATA by Joe Harkness at John Hopkins University. It implements Amemiya's GLS estimator using formulas from Newey (1987)

27 Using a test proposed by Smith and Blundell (1986), the $\chi^{2}(2)=5.82$ (p-value $\left.=0.054\right)$ for new production processes and $\chi^{2}(2)=5.52$ ( $\mathrm{p}$-value $\left.=0.063\right)$ for new products.
} 
the competition policy index also yields a larger result when competition is assumed to be endogenous. $^{28}$

\section{Conclusions And Policy Recommendations}

Earlier empirical studies have shown that competition has an ambiguous effect on innovation in the low and middle-income economies of Eastern Europe and Central Asia. Although pressure from foreign and domestic competitors appears to be positively associated with innovation (Carlin et al., 2001; World Bank, 2004), price competition appears negatively associated with it (Carlin et al., 2001). This paper assesses the net impact of changes in tariffs and competition laws on innovation, by assessing the impact that these policies have on the different aspects of competition.

Firms in low and middle-income countries in Europe and Central Asia feel greater pressure to introduce new products and services and to enter new markets when tariffs are lower. Tariffs also affect firms' perceptions regarding market power. Firms were less likely to say that they believed they could raise prices by 10 percent without losing customers when tariffs were lower. Competition laws also affect competition in these countries. Firms were more likely to say that they felt pressure from competitors and were less likely to say that they could increase prices without losing customers in countries where competition policy was stricter and better enforced.

Because tariffs appear to be negatively associated with pressure from competitors (which is positively associated with innovation) and domestic price competition (which is negatively associated with innovation), the net impact of tariffs on innovation will depend on the magnitudes of the opposing affects. In practice, the net impact appears to be small—although in most cases lower tariffs appear to be associated with less innovation. The point estimates of the parameters suggest that the average firm would be about 0.6 percentage points less likely to introduce a new production process and 0.1 percentage points less likely to introduce a new product if tariffs were set at a uniform 5 percent than if they were set at a uniform 18.3 percent.

\footnotetext{
${ }^{28}$ Increasing the score on the competition policy index from 2.0 to 2.7 would increase the average probabilities by between 4.4 and 3.7 percentage points.
} 
Given that about 43 percent of enterprises introduced new products and 57 percent introduced new production technologies between 1998 and 2001, this appears quite small. Effects remain small when competition is treated as endogenous.

In contrast, competition law appears more likely to have a positive impact on innovation than tariff policy. When competition is treated as exogenous, firms in countries that required pre-merger notification were about 0.9 percentage points less likely to introduce new production processes but 0.5 percentage points more likely to introduce new products. When competition is assumed to endogenous, the effect is positive and significantly larger. Firms in countries that required pre-merger notification were about 4 percentage points more likely to introduce new production processes and 6 percentage points more likely to introduce new products than firms in countries without these requirements.

In most transition economies, the effectiveness of competition law could be improved. In the most recent assessment by the EBRD, few countries had increased their scores on the index of competition policy between the late 1990s and 2003 (European Bank for Reconstruction and Development, 2003). Most countries had made less progress on this dimension of reform than they had on other dimensions - for example, scores on the competition policy index are generally significantly lower than scores on the large-scale privatization index (see Table 8)

Although laws need improving in some countries, for the most part, the problem does not appear to be related to the content of the laws. For example, many of the transition economieswith a few notable exceptions - scored relatively well on the anti-merger index, a measure based on the content of the law rather than on enforcement (see Table 8). This is consistent with evidence from other low and middle-income countries-overall perceptions about the effectiveness of anti-competition law is not highly correlated with the content of the law (World Bank, 2004).

Rather the problem appears to be related to enforcement, especially in countries in the Commonwealth of Independent States and South Eastern Europe. For example, in the EBRD's Legal Indicator Survey in 2002, fewer than 40 percent of respondents in South Eastern Europe said that anti-competitive practices were often investigated and prosecuted in their home country (Vagliasindi and Campbell, 2004). In some countries, such as Tajikistan and Serbia and 
Montenegro, fewer than 20 percent of experts responded that this was the case. Overall, this suggests that there is plenty of scope for improving enforcement in many transition economies. 


\section{TABLES}

Table 1: Utility Patent Applications in the United States, by Country of Origin, 2001.

\begin{tabular}{|c|c|}
\hline & Number of Applications \\
\hline \multicolumn{2}{|l|}{ Selected Industrialized Economies } \\
\hline Belgium & 1,013 \\
\hline France & 5,061 \\
\hline Germany & 14,415 \\
\hline Japan & 45,835 \\
\hline United Kingdom & 5,913 \\
\hline Transition Economies (Total) & 554 \\
\hline Albania & 0 \\
\hline Armenia & 1 \\
\hline Azerbaijan & 1 \\
\hline Belarus & 3 \\
\hline Bosnia \& Herzegovina & 0 \\
\hline Bulgaria & 6 \\
\hline Croatia & 18 \\
\hline Czech Republic & 38 \\
\hline Estonia & 5 \\
\hline Georgia & 4 \\
\hline Hungary & 96 \\
\hline Kazakhstan & 1 \\
\hline Kyrgyz Republic & 0 \\
\hline Latvia & 2 \\
\hline Lithuania & 6 \\
\hline Macedonia & 0 \\
\hline Moldova & 1 \\
\hline Poland & 36 \\
\hline Romania & 8 \\
\hline Russian Federation & 251 \\
\hline Slovakia & 5 \\
\hline Slovenia & 42 \\
\hline Ukraine & 23 \\
\hline Uzbekistan & 1 \\
\hline Yugoslavia & 6 \\
\hline
\end{tabular}

Source: United States Patent and Trademark Office 
Table 2: Sample means and standard deviations.

\begin{tabular}{|c|c|c|c|c|}
\hline & Variable & Obs. & Mean & Std. Dev. \\
\hline $\begin{array}{l}\text { Technology } \\
\text { Developed major new product in past } 3 \text { years } \\
\text { Introduced new production technology }\end{array}$ & $\begin{array}{l}\text { Dummy } \\
\text { Dummy }\end{array}$ & $\begin{array}{l}1626 \\
1625\end{array}$ & $\begin{array}{l}0.43 \\
0.57\end{array}$ & $\begin{array}{l}0.49 \\
0.50\end{array}$ \\
\hline $\begin{array}{l}\text { Competition Indices } \\
\text { Index of price competition } \\
\text { Pressure from foreign competitors } \\
\text { Pressure from domestic competitors }\end{array}$ & $\begin{array}{l}\text { Index }(0-4) \\
\text { Index }(0-4) \\
\text { Index }(0-4)\end{array}$ & $\begin{array}{l}1621 \\
1576 \\
1606\end{array}$ & $\begin{array}{l}2.56 \\
2.35 \\
2.70\end{array}$ & $\begin{array}{l}1.08 \\
1.14 \\
1.04\end{array}$ \\
\hline $\begin{array}{l}\text { Competition Policy } \\
\text { Average Tariff Rate (4-figure ISIC) } \\
\text { Anti-merger Law Index } \\
\text { Days to Register a New Business } \\
\text { EBRD Competition Policy Index } \\
\end{array}$ & $\begin{array}{l}\text { Index (0-3) } \\
\text { Natural Log } \\
\text { Index (0-4) }\end{array}$ & $\begin{array}{l}1518 \\
1516 \\
1584 \\
1487\end{array}$ & $\begin{array}{l}13.49 \\
2.57 \\
3.70 \\
2.21\end{array}$ & $\begin{array}{l}14.47 \\
1.03 \\
0.46 \\
0.55\end{array}$ \\
\hline $\begin{array}{l}\text { Country Controls } \\
\text { Population } \\
\text { Area in Squared Kilometers } \\
\text { Per Capita GDP } \\
\text { Commonwealth of Independent States }\end{array}$ & $\begin{array}{l}\text { Natural Log } \\
\text { Natural Log } \\
\text { Natural Log } \\
\text { Dummy }\end{array}$ & $\begin{array}{l}1633 \\
1542 \\
1633 \\
1633\end{array}$ & $\begin{array}{l}16.37 \\
12.27 \\
7.53 \\
0.42\end{array}$ & $\begin{array}{l}1.30 \\
1.77 \\
0.85 \\
0.49\end{array}$ \\
\hline $\begin{array}{l}\text { Enterprise Controls } \\
\text { Workers } \\
\text { Any Government Ownership } \\
\text { Any Foreign Ownership } \\
\text { De novo private enterprise } \\
\text { Exporter }\end{array}$ & $\begin{array}{l}\text { Natural Log } \\
\text { Dummy } \\
\text { Dummy } \\
\text { Dummy } \\
\text { Dummy }\end{array}$ & $\begin{array}{l}1565 \\
1633 \\
1633 \\
1633 \\
1626\end{array}$ & $\begin{array}{l}4.08 \\
0.19 \\
0.21 \\
0.53 \\
0.51\end{array}$ & $\begin{array}{l}1.66 \\
0.39 \\
0.41 \\
0.50 \\
0.50\end{array}$ \\
\hline
\end{tabular}


Table 3: Impact of trade and competition policy in competition

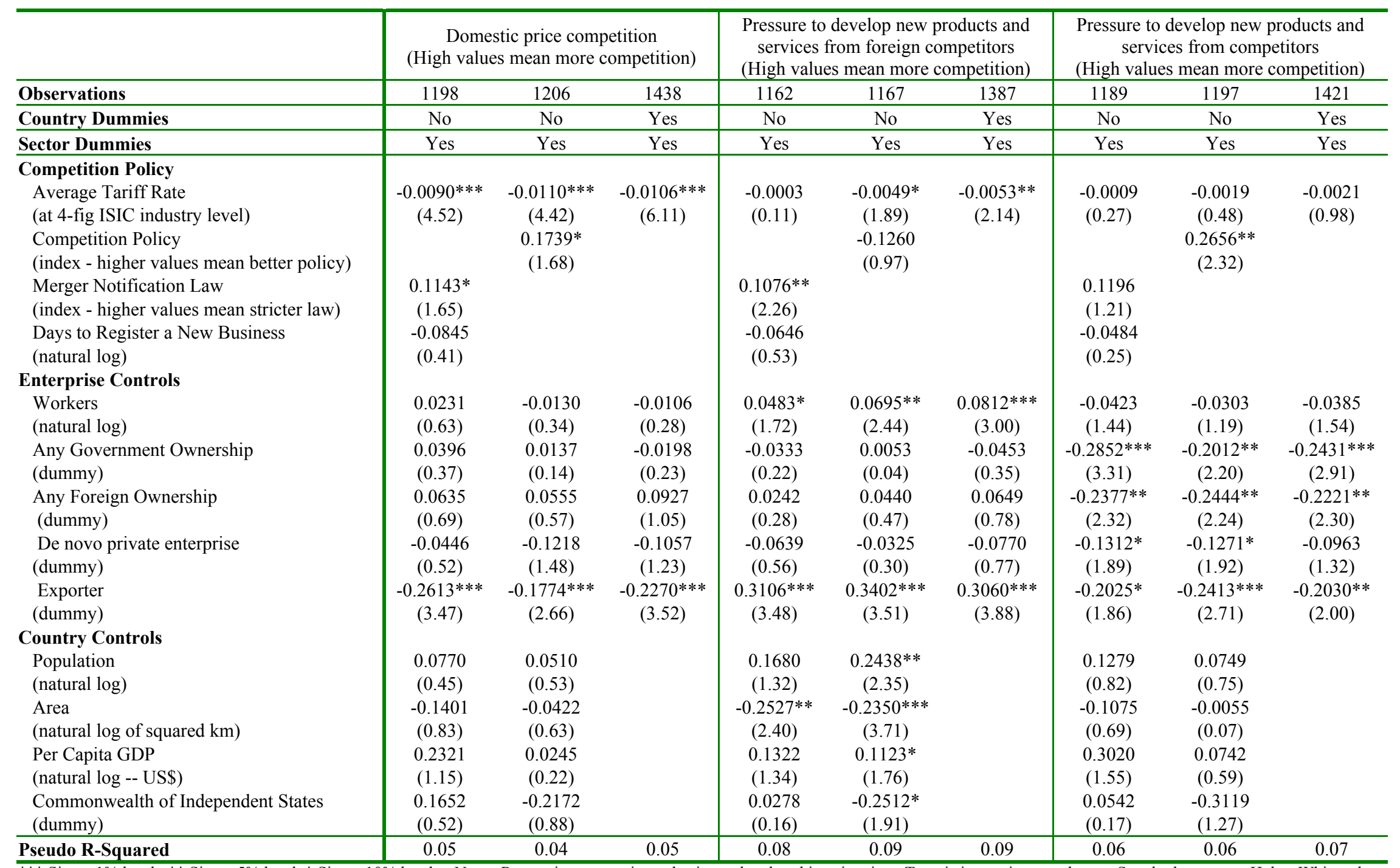

*** Sig. at $1 \%$ level $* *$ Sig. at $5 \%$ level * Sig. at $10 \%$ level. Note: Regressions are estimated using ordered probit estimation. T-statistics are in parentheses. Standard errors are Huber-White robust standard errors allowing error terms to be correlated within countries. Regressions include dummy variables indicating country and sector of operations (at 4-figure ISIC level). 
Table 4: Impact of Competition on Adoption of Production Processes

\begin{tabular}{|c|c|c|c|c|c|c|}
\hline \multirow{2}{*}{$\begin{array}{l}\text { Dependent Variable } \\
\text { Observations }\end{array}$} & \multicolumn{6}{|c|}{$\begin{array}{l}\text { New Process Development } \\
\text { (Dummy) }\end{array}$} \\
\hline & 1394 & 1472 & 1401 & 1447 & 1394 & 1394 \\
\hline Country Dummies & No & Yes & No & No & No & No \\
\hline Sector Dummies & Yes & Yes & Yes & Yes & Yes & Yes \\
\hline \multicolumn{7}{|l|}{ Competition } \\
\hline $\begin{array}{l}\text { Pressure from foreign and domestic competitors } \\
\text { (index - high values mean more competition) } \\
\text { Square of pressure from competitors } \\
\text { (squared index) }\end{array}$ & $\begin{array}{c}0.0528 * * * \\
(3.52)\end{array}$ & $\begin{array}{l}0.0556^{* * *} \\
\quad(3.53)\end{array}$ & $\begin{array}{l}0.0371 * * * \\
\quad(2.65)\end{array}$ & & $\begin{array}{l}0.0103 \\
(0.26) \\
0.0107 \\
(1.06)\end{array}$ & \\
\hline $\begin{array}{l}\text { Domestic price competition } \\
\text { (index - high values mean more competition) } \\
\text { Square of domestic price competition } \\
\text { (squared index) }\end{array}$ & $\begin{array}{c}-0.0606 * * * \\
(5.93)\end{array}$ & $\begin{array}{l}-0.0657 * * * \\
\quad(6.88)\end{array}$ & & $\begin{array}{l}-0.0496^{* * * *} \\
\quad(5.33)\end{array}$ & $\begin{array}{c}-0.0248 \\
(0.36) \\
-0.0068 \\
(0.51)\end{array}$ & $\begin{array}{l}-0.0600^{* * * *} \\
\quad(5.77)\end{array}$ \\
\hline $\begin{array}{l}\text { Pressure from foreign competitors } \\
\text { (index - higher values mean more pressure) } \\
\text { Pressure from domestic competitors } \\
\text { (index - higher values mean more pressure) }\end{array}$ & & & & & & $\begin{array}{c}0.0408^{* *} \\
(2.33) \\
0.0274^{*} \\
(1.79)\end{array}$ \\
\hline \multicolumn{7}{|l|}{ Enterprise Controls } \\
\hline $\begin{array}{l}\text { Workers } \\
\text { (natural } \log \text { ) }\end{array}$ & $\begin{array}{c}0.0312 * * * \\
(2.65)\end{array}$ & $\begin{array}{l}0.0342 * * * \\
\quad(3.02)\end{array}$ & $\begin{array}{c}0.0302^{* *} \\
(2.44)\end{array}$ & $\begin{array}{l}0.0312 * * * \\
(2.66)\end{array}$ & $\begin{array}{l}0.0312 * * * \\
(2.62)\end{array}$ & $\begin{array}{c}0.0305^{* * *} \\
(2.54)\end{array}$ \\
\hline $\begin{array}{l}\text { Any Government Ownership } \\
\text { (dummy) }\end{array}$ & $\begin{array}{c}-0.0952^{* *} \\
(2.00)\end{array}$ & $\begin{array}{l}-0.0930 * * \\
\quad(2.22)\end{array}$ & $\begin{array}{l}-0.0974 * * \\
(2.14)\end{array}$ & $\begin{array}{l}-0.1143 * * \\
\quad(2.30)\end{array}$ & $\begin{array}{c}-0.0940^{*} \\
(1.95)\end{array}$ & $\begin{array}{c}-0.0972 * * \\
(2.02)\end{array}$ \\
\hline $\begin{array}{l}\text { Any Foreign Ownership } \\
\text { (dummy) }\end{array}$ & $\begin{array}{c}-0.0242 \\
(0.60)\end{array}$ & $\begin{array}{c}-0.0199 \\
(0.54)\end{array}$ & $\begin{array}{c}-0.0263 \\
(0.68)\end{array}$ & $\begin{array}{c}-0.0208 \\
(0.52)\end{array}$ & $\begin{array}{c}-0.0224 \\
(0.55)\end{array}$ & $\begin{array}{c}-0.0262 \\
(0.66)\end{array}$ \\
\hline $\begin{array}{l}\text { De novo private enterprise } \\
\text { (dummy) }\end{array}$ & $\begin{array}{c}0.0797^{*} \\
(1.79)\end{array}$ & $\begin{array}{c}0.0754^{*} \\
(1.79)\end{array}$ & $\begin{array}{c}0.0841 * \\
(1.93)\end{array}$ & $\begin{array}{c}0.0674 \\
(1.54)\end{array}$ & $\begin{array}{c}0.0817^{*} \\
(1.82)\end{array}$ & $\begin{array}{c}0.0790 * \\
(1.79)\end{array}$ \\
\hline $\begin{array}{l}\text { Exporter } \\
\text { (dummy) }\end{array}$ & $\begin{array}{l}0.0591^{* *} \\
(2.00)\end{array}$ & $\begin{array}{r}0.0377 \\
(1.43)\end{array}$ & $\begin{array}{l}0.0763 * * * \\
\quad(2.59)\end{array}$ & $\begin{array}{c}0.0622 * * \\
(2.05)\end{array}$ & $\begin{array}{l}0.0595^{* *} \\
(2.04)\end{array}$ & $\begin{array}{c}0.0556^{*} \\
(1.82)\end{array}$ \\
\hline \multicolumn{7}{|l|}{ Country Controls } \\
\hline $\begin{array}{l}\text { Population } \\
\text { (natural log) }\end{array}$ & $\begin{array}{l}0.0290 \\
(0.75)\end{array}$ & & $\begin{array}{l}0.0278 \\
(0.71)\end{array}$ & $\begin{array}{l}0.0337 \\
(0.85)\end{array}$ & $\begin{array}{l}0.0270 \\
(0.67)\end{array}$ & $\begin{array}{c}0.0289 \\
(0.75)\end{array}$ \\
\hline $\begin{array}{l}\text { Area } \\
\text { (natural log of squared km) }\end{array}$ & $\begin{array}{c}-0.0580 * * * \\
(2.66)\end{array}$ & & $\begin{array}{c}-0.0541 * * \\
(2.34)\end{array}$ & $\begin{array}{l}-0.0613^{* * *} \\
\quad(2.78)\end{array}$ & $\begin{array}{c}-0.0558 * * \\
(2.47)\end{array}$ & $\begin{array}{l}-0.0571 * * \\
(2.57)\end{array}$ \\
\hline $\begin{array}{l}\text { Per Capita GDP } \\
\text { (natural log -- US\$) }\end{array}$ & $\begin{array}{c}-0.0127 \\
(0.60)\end{array}$ & & $\begin{array}{c}-0.0220 \\
(1.07)\end{array}$ & $\begin{array}{c}-0.0041 \\
(0.19)\end{array}$ & $\begin{array}{c}-0.0140 \\
(0.64)\end{array}$ & $\begin{array}{c}-0.0123 \\
(0.59)\end{array}$ \\
\hline $\begin{array}{l}\text { Commonwealth of Independent States } \\
\text { (dummy) }\end{array}$ & $\begin{array}{c}0.0873^{*} \\
(1.88) \\
\end{array}$ & & $\begin{array}{c}0.0740 \\
(1.55) \\
\end{array}$ & $\begin{array}{c}0.0756 \\
(1.41) \\
\end{array}$ & $\begin{array}{c}0.0854^{*} \\
(1.80) \\
\end{array}$ & $\begin{array}{c}0.0871^{*} \\
(1.87) \\
\end{array}$ \\
\hline Pseudo R-Squared & 0.09 & 0.11 & 0.08 & 0.08 & 0.09 & 0.09 \\
\hline
\end{tabular}


Table 5: Impact of Competition on New Product Development

\begin{tabular}{|c|c|c|c|c|c|c|}
\hline \multirow{2}{*}{$\begin{array}{l}\text { Dependent Variable } \\
\text { Observations }\end{array}$} & \multicolumn{6}{|c|}{$\begin{array}{c}\text { New Product Development } \\
\text { (Dummy) }\end{array}$} \\
\hline & 1399 & 1477 & 1406 & 1452 & 1399 & 1399 \\
\hline Country Dummies & No & Yes & No & No & No & No \\
\hline Sector Dummies & Yes & Yes & Yes & Yes & Yes & Yes \\
\hline \multicolumn{7}{|l|}{ Competition } \\
\hline $\begin{array}{l}\text { Pressure from foreign and domestic competitors } \\
\text { (index - high values mean more competition) } \\
\text { Square of pressure from competitors } \\
\text { (squared index) }\end{array}$ & $\begin{array}{c}0.0731 * * * \\
\quad(4.91)\end{array}$ & $\begin{array}{c}0.0621 * * * \\
(4.08)\end{array}$ & $\begin{array}{l}0.0640^{* * *} \\
(4.34)\end{array}$ & & $\begin{array}{l}0.1741 * * * \\
\quad(3.58) \\
-0.0255^{* *} \\
(2.26)\end{array}$ & \\
\hline $\begin{array}{l}\text { Domestic price competition } \\
\text { (index - high values mean more competition) } \\
\text { Square of domestic price competition } \\
\text { (squared index) }\end{array}$ & $\begin{array}{c}-0.0309 * * \\
(2.07)\end{array}$ & $\begin{array}{l}-0.0420 * * * \\
\quad(3.16)\end{array}$ & & $\begin{array}{c}-0.0167 \\
(1.15)\end{array}$ & $\begin{array}{c}-0.0870 \\
(1.48) \\
0.0106 \\
(0.98)\end{array}$ & $\begin{array}{l}-0.0303 * * \\
(2.04)\end{array}$ \\
\hline $\begin{array}{l}\text { Pressure from foreign competitors } \\
\text { (index - higher values mean more pressure) } \\
\text { Pressure from domestic competitors } \\
\text { (index - higher values mean more pressure) }\end{array}$ & & & & & & $\begin{array}{c}0.0538 * * * \\
(4.31) \\
0.0409 * * \\
(2.50)\end{array}$ \\
\hline \multicolumn{7}{|l|}{ Enterprise Controls } \\
\hline $\begin{array}{l}\text { Workers } \\
\text { (natural } \log \text { ) }\end{array}$ & $\begin{array}{c}0.0653 * * * \\
(5.77)\end{array}$ & $\begin{array}{l}0.0613 * * * \\
(5.15)\end{array}$ & $\begin{array}{l}0.0631 * * * \\
(5.25)\end{array}$ & $\begin{array}{l}0.0643 * * * \\
(5.45)\end{array}$ & $\begin{array}{l}0.0654 * * * \\
(5.80)\end{array}$ & $\begin{array}{l}0.0646^{* * *} \\
\quad(5.50)\end{array}$ \\
\hline $\begin{array}{l}\text { Any Government Ownership } \\
\text { (dummy) }\end{array}$ & $\begin{array}{c}-0.1557 * * * \\
(3.08)\end{array}$ & $\begin{aligned}- & -0.1439 * * * \\
& (2.74)\end{aligned}$ & $\begin{array}{c}-0.1577 * * * \\
(3.14)\end{array}$ & $\begin{array}{c}-0.1753 * * * \\
\quad(3.52)\end{array}$ & $\begin{array}{c}-0.1584^{* * * *} \\
\quad(3.17)\end{array}$ & $\begin{array}{c}-0.1577 * * * \\
\quad(3.16)\end{array}$ \\
\hline $\begin{array}{l}\text { Any Foreign Ownership } \\
\text { (dummy) }\end{array}$ & $\begin{array}{c}-0.0190 \\
(0.45)\end{array}$ & $\begin{array}{c}-0.0243 \\
(0.64)\end{array}$ & $\begin{array}{c}-0.0181 \\
(0.43)\end{array}$ & $\begin{array}{c}-0.0150 \\
(0.39)\end{array}$ & $\begin{array}{c}-0.0228 \\
(0.55)\end{array}$ & $\begin{array}{c}-0.0212 \\
(0.51)\end{array}$ \\
\hline $\begin{array}{l}\text { De novo private enterprise } \\
\text { (dummy) }\end{array}$ & $\begin{array}{c}0.1542 * * * \\
(3.97)\end{array}$ & $\begin{array}{l}0.1595 * * * \\
(4.07)\end{array}$ & $\begin{array}{l}0.1536 * * * \\
(3.91)\end{array}$ & $\begin{array}{l}0.1410 * * * \\
(3.60)\end{array}$ & $\begin{array}{l}0.1508 * * * \\
\quad(3.86)\end{array}$ & $\begin{array}{l}0.1538 * * * \\
(3.97)\end{array}$ \\
\hline $\begin{array}{l}\text { Exporter } \\
\text { (dummy) }\end{array}$ & $\begin{array}{l}0.1095 * * * \\
\quad(2.89)\end{array}$ & $\begin{array}{l}0.1108 * * * \\
\quad(2.70)\end{array}$ & $\begin{array}{l}0.1207 * * * \\
\quad(3.08)\end{array}$ & $\begin{array}{l}0.1275^{* * *} * \\
\quad(3.18)\end{array}$ & $\begin{array}{l}0.1084 * * * \\
\quad(2.80)\end{array}$ & $\begin{array}{l}0.1054 * * * \\
\quad(2.83)\end{array}$ \\
\hline \multicolumn{7}{|l|}{ Country Controls } \\
\hline $\begin{array}{l}\text { Population } \\
\text { (natural log) }\end{array}$ & $\begin{array}{c}-0.0429 \\
(1.08)\end{array}$ & & $\begin{array}{c}-0.0440 \\
(1.13)\end{array}$ & $\begin{array}{c}-0.0256 \\
(0.62)\end{array}$ & $\begin{array}{c}-0.0377 \\
(0.95)\end{array}$ & $\begin{array}{c}-0.0430 \\
(1.08)\end{array}$ \\
\hline Area & 0.0200 & & 0.0227 & 0.0077 & 0.0146 & 0.0209 \\
\hline (natural log of squared $\mathrm{km}$ ) & $(0.71)$ & & $(0.81)$ & $(0.28)$ & $(0.53)$ & $(0.74)$ \\
\hline Per Capita GDP & -0.0549 & & -0.0619 & -0.0322 & -0.0526 & -0.0542 \\
\hline (natural log -- US\$) & $(1.11)$ & & $(1.29)$ & $(0.68)$ & $(1.05)$ & (1.10) \\
\hline Commonwealth of Independent States & 0.1487 & & 0.1387 & 0.1482 & 0.1541 & 0.1486 \\
\hline$\frac{\text { (dummy) }}{\text { Pseudo R-Squared }}$ & $\begin{array}{c}(1.54) \\
0.12\end{array}$ & 0.16 & $\begin{array}{c}(1.44) \\
0.12\end{array}$ & $\begin{array}{c}(1.55) \\
0.11\end{array}$ & $\begin{array}{c}(1.60) \\
0.13\end{array}$ & $\begin{array}{c}(1.54) \\
0.12\end{array}$ \\
\hline
\end{tabular}


Table 6: Effect of adding additional measures of competition and pressure to innovate

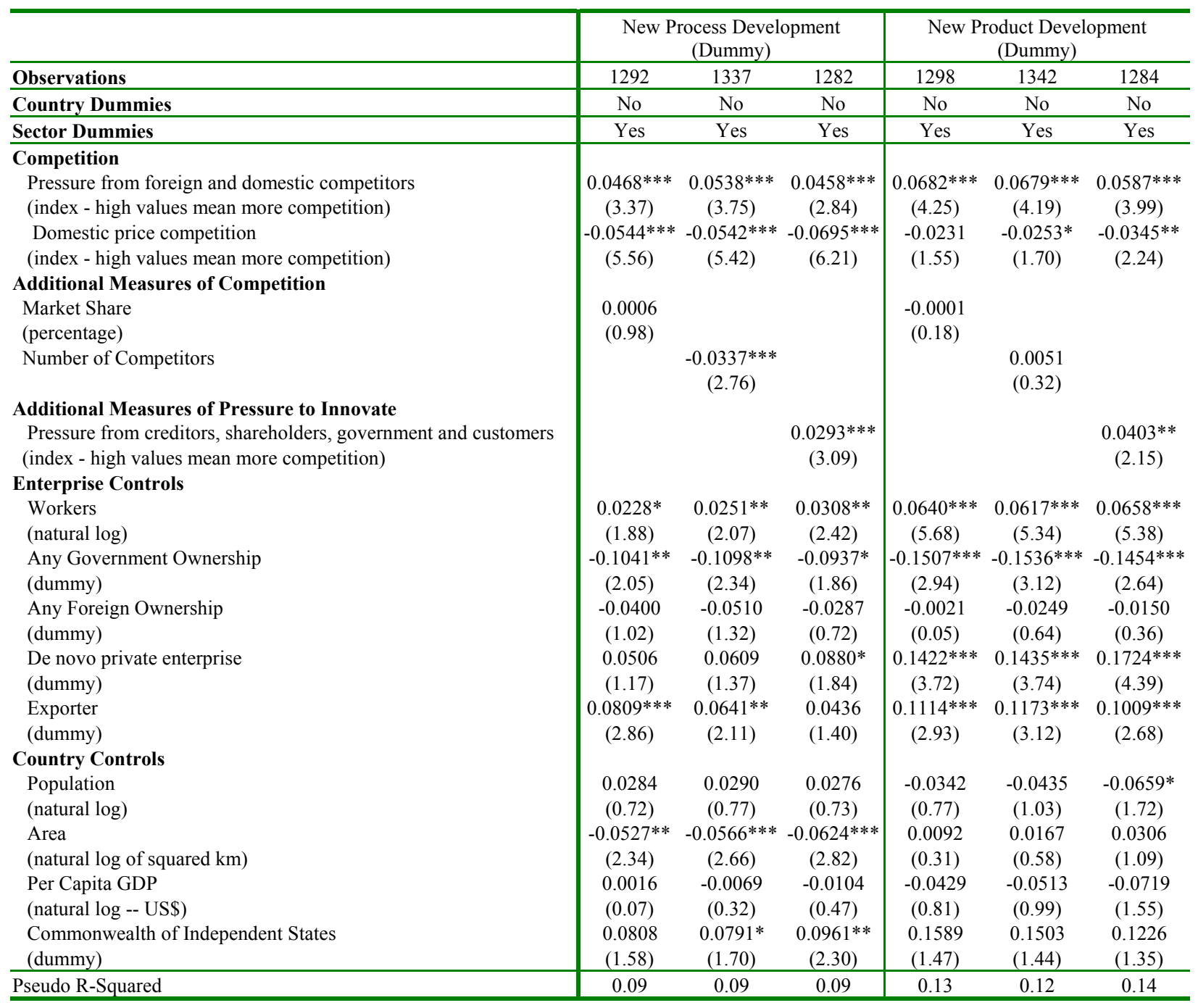


Table 7: Impact of Competition on New Product Development allowing competition to be determined endogenously

\begin{tabular}{|c|c|c|c|c|}
\hline \multirow[b]{2}{*}{ Observations } & \multicolumn{2}{|c|}{$\begin{array}{l}\text { New Product Development } \\
\text { (Dummy) }\end{array}$} & \multicolumn{2}{|c|}{$\begin{array}{c}\text { New Process Development } \\
\text { (Dummy) }\end{array}$} \\
\hline & 1155 & 1149 & 1144 & 1138 \\
\hline \multicolumn{5}{|l|}{ Country Dummies } \\
\hline \multicolumn{5}{|l|}{ Sector Dummies } \\
\hline $\begin{array}{l}\text { Competition } \\
\text { Index of pressure from foreign and domestic competitors } \\
\text { (index - high values mean more competition) } \\
\text { Index of price competition } \\
\text { (index - high values mean more competition) }\end{array}$ & $\begin{array}{c}0.4727^{*} \\
(1.89)\end{array}$ & $\begin{array}{c}0.5409 * * \\
(1.98) \\
-0.1397 \\
(0.64)\end{array}$ & $\begin{array}{c}0.3963^{*} \\
(1.73)\end{array}$ & $\begin{array}{c}0.5003^{*} \\
(1.89) \\
-0.1632 \\
(0.77)\end{array}$ \\
\hline \multicolumn{5}{|l|}{ Enterprise Controls } \\
\hline $\begin{array}{l}\text { Workers } \\
\text { (natural log) }\end{array}$ & $\begin{array}{l}0.0593 * * * \\
(3.45)\end{array}$ & $\begin{array}{c}0.0627 * * * \\
(3.46)\end{array}$ & $\begin{array}{l}0.0260 \\
(1.62)\end{array}$ & $\begin{array}{c}0.0299 * \\
(1.70)\end{array}$ \\
\hline $\begin{array}{l}\text { Any Government Ownership } \\
\text { (dummy) }\end{array}$ & $\begin{array}{c}-0.0316 \\
(0.36)\end{array}$ & $\begin{array}{c}-0.0149 \\
(0.16)\end{array}$ & $\begin{array}{c}-0.0700 \\
(0.85)\end{array}$ & $\begin{array}{c}-0.0462 \\
(0.49)\end{array}$ \\
\hline $\begin{array}{l}\text { Any Foreign Ownership } \\
\text { (dummy) }\end{array}$ & $\begin{array}{c}0.0298 \\
(0.47)\end{array}$ & $\begin{array}{r}0.0347 \\
(0.50)\end{array}$ & $\begin{array}{c}0.0066 \\
(0.11)\end{array}$ & $\begin{array}{l}0.0171 \\
(0.25)\end{array}$ \\
\hline $\begin{array}{l}\text { De novo private enterprise } \\
\text { (dummy) }\end{array}$ & $\begin{array}{l}0.1956^{* * * *} \\
(3.18)\end{array}$ & $\begin{array}{l}0.1894 * * * \\
(2.96)\end{array}$ & $\begin{array}{l}0.0871 \\
(1.53)\end{array}$ & $\begin{array}{l}0.0796 \\
(1.30)\end{array}$ \\
\hline $\begin{array}{l}\text { Exporter } \\
\text { (dummy) }\end{array}$ & $\begin{array}{l}0.1103^{* *} \\
(1.97)\end{array}$ & $\begin{array}{r}0.0657 \\
(0.78)\end{array}$ & $\begin{array}{c}0.0618 \\
(1.19)\end{array}$ & $\begin{array}{c}0.0088 \\
(0.11)\end{array}$ \\
\hline \multicolumn{5}{|l|}{ Country Controls } \\
\hline $\begin{array}{l}\text { Population } \\
\text { (natural log) }\end{array}$ & $\begin{array}{l}-0.1681 * * * \\
(2.82)\end{array}$ & $\begin{array}{l}-0.1586^{* * *} \\
(2.67)\end{array}$ & $\begin{array}{c}-0.0564 \\
(1.01)\end{array}$ & $\begin{array}{c}-0.0471 \\
(0.82)\end{array}$ \\
\hline $\begin{array}{l}\text { Area } \\
\text { (natural log of squared } \mathrm{km} \text { ) }\end{array}$ & $\begin{array}{c}0.1399 * * \\
(2.47)\end{array}$ & $\begin{array}{c}0.1290 * * \\
(2.28)\end{array}$ & $\begin{array}{c}0.0318 \\
(0.60)\end{array}$ & $\begin{array}{c}0.0214 \\
(0.39)\end{array}$ \\
\hline $\begin{array}{l}\text { Per Capita GDP } \\
\text { (natural log -- US\$) }\end{array}$ & $-0.2158 * * *$ & $-0.1937 * *$ & $\begin{array}{c}-0.1052 \\
(1.54)\end{array}$ & $\begin{array}{c}-0.0837 \\
(1.13)\end{array}$ \\
\hline $\begin{array}{l}\text { Commonwealth of Independent States } \\
\text { (dummy) }\end{array}$ & $\begin{array}{c}0.1254^{*} \\
(1.70)\end{array}$ & $\begin{array}{c}0.1555^{*} \\
(1.88)\end{array}$ & $\begin{array}{l}0.1064 \\
(1.52)\end{array}$ & $0.1451^{*}$ \\
\hline Pseudo R-Squared & 0.13 & 0.13 & 0.08 & 0.08 \\
\hline
\end{tabular}


Table 8: Competition policy indices in sample countries, 2001.

\begin{tabular}{|c|c|c|c|c|}
\hline & $\begin{array}{c}\text { Average Tariff } \\
\text { (firms in sample) }\end{array}$ & $\begin{array}{c}\text { Anti-merger } \\
\text { law }\end{array}$ & $\begin{array}{c}\text { EBRD Competition } \\
\text { Index }\end{array}$ & $\begin{array}{l}\text { EBRD Large-Scale } \\
\text { Privatization Index }\end{array}$ \\
\hline Albania & 15.1 & 3 & 1.7 & 2.3 \\
\hline Armenia & 4.6 & 0 & 2 & 3.3 \\
\hline Azerbaijan & 11.0 & 3 & 2 & 2 \\
\hline Belarus & 15.9 & 3 & 2 & 1 \\
\hline Bosnia and Herzegovina & 8.9 & -- & 1 & 2.3 \\
\hline Bulgaria & 21.9 & 3 & 2.3 & 3.7 \\
\hline Croatia & 12.4 & 3 & 2.3 & 3 \\
\hline Czech & 5.8 & 3 & 3 & 4 \\
\hline Estonia & 0.5 & 3 & 2.7 & 4 \\
\hline FYROM & 26.3 & 3 & 2 & 3 \\
\hline Georgia & -- & 0 & 2 & 3.3 \\
\hline Hungary & 16.9 & 3 & 3 & 4 \\
\hline Kazakhstan & --- & 3 & 2 & 3 \\
\hline Kyrgyz Republic & 10.4 & & 2 & 3 \\
\hline Latvia & 4.8 & 3 & 2.3 & 3.3 \\
\hline Lithuania & 9.6 & 3 & 3 & 3.7 \\
\hline Moldova & 11.4 & 3 & 2 & 3 \\
\hline Poland & 19.4 & 3 & 3 & 3.3 \\
\hline Romania & 23.8 & 3 & 2.3 & 3.3 \\
\hline Russia & 10.7 & 3 & 2.3 & 3.3 \\
\hline Slovakia & 28.0 & 2 & 3 & 4 \\
\hline Slovenia & 11.3 & 3 & 2.7 & 3 \\
\hline Tajikistan & 10.4 & 0 & 1.7 & 2.3 \\
\hline Turkey & 8.5 & 3 & --- & -- \\
\hline Ukraine & 11.8 & 3 & 2.3 & 3 \\
\hline Uzbekistan & 12.4 & 3 & 2 & 2.7 \\
\hline Serbia and Montenegro & --- & 0 & 1 & 2 \\
\hline
\end{tabular}




\section{Reference List}

Aghion, Philippe, Mathias Dewatripont, and Patrick Rey, 1999. "Competition, Financial Discipline, and Growth." Review of Economic Studies 66 (4), 825-852.

Aghion, Philippe, Christopher Harris, Peter Howitt, and John Vickers, 2001. "Competition, Imitation and Growth with Step-by-Step Innovation." Review of Economic Studies 68 (3), 467-492.

Baker, Jonathan B, 2003. "The Case for Antitrust Enforcement." Journal of Economic Perspectives 17 (4), 27-50.

Bartelsman, Eric, John Haltiwanger, and Stefano Scarpetta, 2004. "Microeconomic Evidence of Creative Destruction in Industrial and Developing Countries." Manuscript, World Bank, Washington DC.

Bastos, Fabiano and John Nasir, 2004. "Productivity and the Investment Climate: What Matters Most?" Policy Research Working Paper \#3335, World Bank, Washington DC.

Carlin, Wendy, Steven Fries, Mark Schaffer, and Paul Seabright, 2001. "Competition and Enterprise Performance in Transition Economies: Evidence from a Cross-Country Survey." Working Paper \#63, European Bank for Reconstruction and Development, London UK.

Crandall, Robert W. and Clifford Winston, 2003. "Does Antitrust Policy Improve Consumer Welfare? Assessing the Evidence." Journal of Economic Perspectives 17 (4), 3-26.

CUTS Center for Competition, Investment and Economic Regulation, ed., 2003. Pulling Up Our Socks: A Study of Competition Regimes of Seven Developing Countries of Africa and Asia under the 7-UP Project. Jaipur Printers, Jaipur, India.

Dasgupta, Partha and Joseph E. Stiglitz, 1980. "Industrial Structure and the Nature of Innovative Activity." Economic Journal 90 (2), 266-293.

Djankov, Simeon and Peter Murrell, 2002. "Enterprise Restructuring in Transition: A Quantitative Survey." Journal of Economic Literature 40 (3), 739-792.

Dutz, Mark and Maria Vagliasindi, 2000. "Competition Policy Implementation in Transition Economies: An Empirical Assessment." European Economic Review 44 (4-6), 762-772.

Economic and Social Research Foundation (ESRF), 2002. Competition Law and Policy -- A Tool for Development in Tanzania. CUTS Center for International Trade, Economics and Environment, Jaipur, India. 
Encaoua, David and Abraham Hollander, 2002. "Competition Policy and Innovation." Oxford Review of Economic Policy 18 (1), 63-79.

European Bank for Reconstruction and Development, 2003. Transition Report 2003: Integration and Regional Cooperation. European Bank for Reconstruction and Development, London, UK.

Evenett, Simon J., 2003. "Links Between Development and Competition Law in Developing Countries." Manuscript, Oxford University, Oxford, UK.

Fries, Steven, Tatiana Lysenko, and Saso Polenac, 2003. "The 2002 Business Environment and Enterprise Performance Survey: Results from a Survey of 6100 Firms." Manuscript, European Bank for Reconstruction and Development, London UK.

Harrison, Ann E., 1994. "Productivity, Imperfect Competition and Trade Reform: Theory and Evidence." Journal of International Economics 36 (1-2), 53-73.

Hellman, Joel and Daniel Kaufmann, 2002. "The Inequality of Influence." Manuscript, World Bank, Washington DC.

Hicks, John R., 1935. "Annual Survey of Economic Theory: The Theory of Monopoly." Econometrica 31 (1), 1-20.

Hoekman, Bernard, Hiau Looi Kee, and Marcelo Olarreaga, 2001. "Markups, Entry Regulations, and Trade: Does Country Size Matter?" Policy Research Working Paper Series \#2662, World Bank, Washington, D.C.

Huber, Peter J., 1967. "The Behavior of Maximum-Likelihood Estimates under Non-Standard Conditions." In: L. M. LeCam and J. Neyman, eds. Proceedings of the Fifth Berkeley Symposium in Mathematical Statistics and Probability. University of California Press, Berkeley, CA, pp. 221-233.

Kee, Hiau Looi and Bernard Hoekman, 2003. "Imports, Entry, and Competition Law as Market Disciplines." Policy Research Working Paper Series \#3031, World Bank, Washington, D.C.

Levinsohn, James, 1993. "Testing the Imports-as-Market-Discipline Hypothesis." Journal of International Economics 35 (1-2), 1-22.

Mansfield, Edwin, Mark Schwarz, and Samuel Wagner, 1981. "Imitation Costs and Patents: An Empirical Study." Economic Journal 91 (364), 907-918.

Moulton, Brent R., 1986. "Random Group Effects and the Precision of Regression Estimates." Journal of Econometrics 32 (3), 386-397.

Newey, Whitney K, 1987. "Efficient Estimation of Limited Dependent Variable Models with Endogenous Explanatory Variables." Journal of Econometrics 36 (3), 231-250. 
Nicholson, Michael W., 2003. "Quantifying Antitrust Regimes." Manuscript, Federal Trade Commission, Washington, D.C.

Nickell, Stephen J., 1996. "Competition and Corporate Performance." Journal of Political Economy 104 (4), 724-746.

Porter, Michael E, Klaus Shwab, Xavier Sala-i-Martin, and Augusto Lopez-Claros, 2004. The Global Competitiveness Report 2003-4. World Economic Forum, Geneva, Switzerland.

Roberts, Mark J. and James R. Tybout, eds., 1996. Industrial Evolution in Developing Countries. Oxford University Press for the World Bank, Washington, D.C.

Rogers, W. H., 1993. "Regression Standard Errors in Clustered Samples." Stata Technical Bulletin Reprints 3 (1), 88-94.

Smith, Adam, 1776. An Inquiry into the Nature and Causes of the Wealth of Nations. University of Chicago, Chicago.

Smith, Richard J. and Richard W. Blundell, 1986. "An Exogeneity Test for a Simultaneous Equation Tobit Model with an Application to Labor Supply." Econometrica 54 (4), 679686.

Tybout, James R., 2003. "Plant- and Firm-Level Evidence on "New" Trade Theories." In: E. Kwan Choi and James Harrigan, eds. Handbook of International Trade. Blackwell Publishers, Malden, MA, pp. 389-415.

United Nations Conference on Trade and Development, 2003. "Model Law on Competition." UNCTAD Series on Issues in Competition Law and Policy \#TD/B/RBP/CONF.5/7/Rev.1, Geneva, Switzerland.

Vagliasindi, Maria, 2001. "Competition across Transition Economies: an Enterprise-level Analysis of the Main Policy and Structural Determinants." Working Paper \#68, European Bank for Reconstruction and Development, London UK.

Vagliasindi, Maria and Laura Campbell, 2004. "Focus on Competition law and Policy: Enhancing Enforcement and Cooperation." Law in Transition 2004 (1), 32-43.

Werden, Gregory G., 2004. "The Effect of Antitrust Policy on Consumer Welfare: What Crandall and Winston Overlook." Related Publication \#04-09, AEI-Brookings Joint Center for Regulatory Studies, Washington DC.

White and Case LLP, 2004. Worldwide Antitrust Merger Notification Requirements: The Guide to 134 Jurisdictions 2003-2004 Edition. White and Case, Washington DC.

World Bank, 2002. Globalization, Growth and Poverty. World Bank, Washington DC.

World Bank, 2003. Doing Business in 2004. World Bank, Washington DC. 
World Bank, 2004. World Development Report 2005: A Better Investment Climate For Everyone. World Bank, Washington DC. 